\title{
The speech-language-hearing pathologist's training to work in education: what speech-language-hearing undergraduate students have to say
}

\author{
Luciana Figueiredo de Oliveira ${ }^{1}$ \\ https://orcid.org/0000-0003-1796-0318 \\ Ivonaldo Leidson Barbosa Lima ${ }^{1,2}$ \\ https://orcid.org/0000-0003-1716-1575 \\ Janaína von Söhsten Trigueiro ${ }^{1}$ \\ https://orcid.org/0000-0003-2926-1450 \\ Brunna Thais Luckwu de Lucena ${ }^{1}$ \\ https://orcid.org/0000-0003-4179-6773 \\ Emanuelly Barbosa da Silva ${ }^{3}$ \\ https://orcid. org/0000-0001-6489-9981 \\ Ariela de Queiroz Correia Nóbrega ${ }^{3}$ \\ https://orcid.org/0000-0001-6957-9899 \\ Kyrlian Bartira Bortolozzi ${ }^{4}$ \\ https://orcid.org/0000-0002-7169-3719
}

Universidade Federal da Paraíba - UFPB, Departamento de Fonoaudiologia, João Pessoa, Paraíba, Brasil.

Centro Universitário de João Pessoa UNIPÊ, Departamento de Fonoaudiologia, João Pessoa, Paraíba, Brasil.

Universidade Federal da Paraíba - UFPB, Curso de Fonoaudiologia, João Pessoa, Paraíba, Brasil.

Universidade Estadual do CentroOeste - UNICENTRO, Departamento de Fonoaudiologia, Irati, Paraná, Brasil.

This research was developed in the Department of Speech-Language-Hearing at the Universidade Federal da Paraíba UFPB, João Pessoa, Paraíba, Brasil.

Conflict of interests: Nonexistent

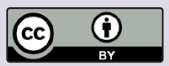

Received on: July 6, 2020

Accepted on: November 18, 2020

Corresponding address:

Luciana Figueiredo de Oliveira

Universidade Federal da Paraíba

Centro de Ciências da Saúde - Campus I, Departamento de Fonoaudiologia. Cidade Universitária - Campus I - Castelo Branco CEP:58051-900 - João Pessoa, Paraíba, Brasil

E-mail: lucianafigueiredo@ccs.ufpb.br

\section{ABSTRACT}

Purpose: to discuss the speech-language-hearing pathologist's training to work in education, based on the report from speech-language-hearing students.

Methods: a total of 29 students in the seventh semester of the Speech-LanguageHearing program at two higher education institutions participated in this study. The questionnaire used was developed specifically for this study. It comprised open- and closed-ended questions on the profile of the students and their training to work in educational settings. Data were also collected on the syllabi of the courses related to Educational Speech-Language-Hearing Pathology at both institutions. The data were quantitatively and qualitatively analyzed.

Results: the results indicated that the summed course load of the education-related courses is low, and their syllabi do not cover important aspects for the speech-language-hearing training aimed at the work in education. Also, the students reported that most of the practical activities took place in kindergarten or elementary school, with objectives related to a medical-centered view. The students also pointed out the need for improvements in the speech-language-hearing training to work in education.

Conclusion: the students reported that their training should involve a broader course load, as well as contents and experiences to help them to consciously, critically, and responsibly join the educational setting.

Keywords: Speech, Language and Hearing Sciences; Education; Education, Higher; Students 


\section{INTRODUCTION}

Studies approaching the speech-language-hearing (SLH) pathologist's professional training generally point out that it bears the marks and traces of a predominantly rehabilitating focus, favoring clinical settings. They also refer that, to train professionals capable of working in line with the principles of comprehensiveness, universality, equity, decentralization, and community participation proposed by the Brazilian Sistema Único de Saúde (Public Health System), the training practices should transcend the specialized, curative assistance model centered only on outpatient and hospital care - which, still today, predominates in SLH Sciences university programs ${ }^{1,2}$. The pieces of research approaching the SLH pathologist's training to work in education are still scarce. However, recent studies in the field point to the urgency of reflecting on what has been proposed for both initial and continued education, as well as in-service training of SLH pathologists who have been working in this field ${ }^{3-7}$.

Currently, both the training and work of the educational SLH pathologist have been mostly guided by the Federal SLH Council Council - Conselho Federal de Fonoaudiologia (CFFa), based on Resolution no. $387 / 2010^{8}$, which covers the practices to be developed by the professionals specialized in this field. The document evolved from Resolution no. 309/2005', which deals with the work of the SLH pathologist in preschool, K-12, special education, and higher education, with an essentially preventive approach.

After Resolution no. 387 was promulgated, the shift of the SLH pathologist's work from the objects of SLH study to the teaching/learning process took place. This document, which approaches the competencies of the educational SLH pathologist, explains that this professional must be acquainted with public education policies, and programs, projects, and actions related to the teaching-learning process, as well as the interrelationship between the SLH aspects and the learning processes and methods in regular and special education. Therefore, they must work in partnership with educators, cooperating with the teaching-learning process, offering educational consultancy, advice, administration, in consonance with the existing public and private educational policies, programs, and projects. Resolution no. 387, promulgated in 2010, also explains that the educational SLH pathologist can work in all administrative levels, in all governing bodies, covering all levels and modes of education ${ }^{8}$.
However, despite the advances in the relationship between SLH and Education and the scope of practice of the educational SLH pathologist broadened to the whole school community, a biomedical bias still prevails in this document, with traces of a preventive approach that has historically been the grounds of SLH training and thus guides the practices of the educational SLH pathologist, whose character is still strongly medicalized ${ }^{5,10}$.

Moreover, to account for competencies and attributes described in Resolution no. 387 of 2010, the SLH pathologist's training must also include theoretical contents and guidelines that go beyond the clinical and technicist practices and reductionist views ${ }^{7}$. Hence, their training must not only encompass the various needs arising from the school communities but also be committed to promoting the quality of life and consequently a quality education, for the SLH pathologist to shift from a clinician to a health educator ${ }^{3}$.

In this sense, the resolutions refer to the promotion, prevention, institutional diagnosis, and intervention actions with preventive, educative, formative, informative, instructive, and continuing education practices, emphasizing that the SLH pathologist cannot offer clinical/therapeutic services within the educational institutions, as their practice must be exclusively educational. However, the manner how such practices are guided still raises concern ${ }^{5,10-12}$.

It is understood that the practices of the educational SLH pathologist are directly related to the reflections and experiences they had in their training. Therefore, it is necessary to reflect on the possibilities presented in the SLH training to those who, once graduated, may choose Education as their field of practice. Considering the abovementioned issues, as well as the scarcity of studies discussing SLH training, particularly focusing on the educational field, it is fitting to listen to the opinion of the SLH students regarding their training to work in the field of education. Just as the other people involved in the training (professors, technicians, patients who attend the services provided by the institution itself, and others related to it), the students must have their voices heard and play an active role in the process of necessary changes in the SLH curriculum, in consonance with studies already mentioned in this text ${ }^{13}$.

Hence, this study aimed to discuss the SLH training to work with education, based on what is reported by SLH college students. 


\section{METHODS}

The research was submitted, for ethical analysis of the procedures, to the Research Ethics Committee of the Department of Health Sciences of the Universidade Federal da Paraíba - UFPB, Paraíba, Brazil, complying with Resolution no. 466/12 of the Conselho Nacional de Saúde (CNS, National Health Council), having been approved under evaluation report no. 66692. All the participants signed the informed consent form (ICF), confirming they agreed to participate in the study. This is both a quantitative and qualitative, descriptive, documental research.

The subjects of the research were SLH students of two higher education institutions (HEI) situated in the Northeast of Brazil. The sample was selected by convenience, with the following inclusion criteria: SLH students in their seventh semester, having already taken the course on Educational SLH Pathology. The exclusion criteria were the student's nonagreement to participate and not having taken the course on Educational SLH Pathology.

Hence, a total of 29 students, from two different classes of the two $\mathrm{HEl}$ - respectively identified here as HEI-A and HEI-B - participated in this study. The $7^{\text {th }}$-semester classes were chosen because the course on Educational SLH Pathology is offered in the sixth semester of the SLH program in both HEI. Regarding the profile of the research's participants, 18 were enrolled in HEl-A (public) and 11 in HEI-B (private); most of them (24) were females; 24 reported being from 20 to 25 years old; only one had a previous college degree.

The data were collected with a questionnaire developed specifically for this study, based on gaps and questionings suggested in previous studies in the field. The instrument had 13 open- and closed-ended questions related to the students' profile (sex, age, the semester in which they were enrolled, and a previous college degree) and the educational SLH pathologist's training and work (courses offered at the university name, course load, profile, time in the program when it is offered - circumstances of practices experienced during the training - level, modality, and educational setting where the practical activities take place - objectives of the educational SLH pathologists' work, and students' opinion regarding the training to work in education).

The data presented in this research also included information on the curriculum of SLH undergraduate programs present on the websites of the institutions in which the participants were enrolled. Such data refer to the syllabus and course load of all the educationrelated courses mentioned by the students, as well as the total course load of the SLH programs in both HEI in which the students were enrolled.

The quantitative data were descriptively analyzed based on the distribution of absolute frequencies and relative percentages. The open-ended questions were categorized and descriptively analyzed. The results were presented in the following theme categories: 1) Education-related courses; 2) educational settings where the practical activities were experienced during graduation; 3) objectives of the educational SLH pathologist's work; and 4) students' report on the SLH training to work in education.

\section{RESULTS}

\section{Education-related courses}

Figure 1 presents data regarding the courses offered in each HEI. It is possible to observe that in HEI-A, the students reported that, during the SLH program, there are four education-related courses they can take, two of which are elective. The summed course load of the required courses was of 105 hours. In HEl-B, only one course was described, whose course load was of 60 hours. 


\begin{tabular}{|c|c|c|}
\hline Course & Characteristics & Course load \\
\hline \multicolumn{3}{|c|}{ HEI-A } \\
\hline Educational Speech-Language-Hearing Pathology & $\begin{array}{c}\text { Required } \\
\text { Theoretical/practical }\end{array}$ & 60 \\
\hline Special Education in the Inclusive Perspective & $\begin{array}{c}\text { Required } \\
\text { Theoretical } \\
\end{array}$ & 45 \\
\hline Education Policies and Administration & $\begin{array}{c}\text { Elective } \\
\text { Theoretical }\end{array}$ & 60 \\
\hline Assessment of Learning & $\begin{array}{c}\text { Elective } \\
\text { Theoretical }\end{array}$ & 45 \\
\hline \multicolumn{3}{|c|}{ HEI-B } \\
\hline Applied Educational Speech-Language-Hearing Pathology & $\begin{array}{c}\text { Required } \\
\text { Theoretical/practical }\end{array}$ & 60 \\
\hline
\end{tabular}

Captions: HEI-A: higher education institution A; HEI-B: higher education institution B

Figure 1. Information on the education-related courses taken in the Speech-Language-Hearing undergraduate training at the institutions in which the participants of the research were enrolled

Regarding the required courses' syllabus, "Health promotion in the school environment" and "Inclusion at school", the content is common to the courses specifically directed to educational SLH pathology, in both HEI. Also, the syllabi of the courses aim at SLH pathologist's practice in the schools. In HEl-A, the syllabus of the course on Special Education in Inclusive Education is focused on the assessment, diagnosis, and treatment of communication disorders.

\section{Educational settings where the practical activities were experienced during the training}

The participants reported that the practical components are present only in the courses on Educational SLH Pathology (HEI-A) and Applied Educational SLH Pathology (HEI-B). However, the course load regarding these components was not described.
Concerning the settings where the practices took place during the training, the data in Table 1 show that most of these activities are carried out in public elementary schools. It is important to point out that, in this question, the participant can check more than one option.

\section{Objectives of the educational SLH pathologist's work}

Concerning the objectives proposed specifically by the practical activities, most of the participants helped in the teaching-learning process (38\%); as for the general objectives of the educational SLH pathologist's work, most of the SLH students indicated that this professional's purpose is "to perform activities with the teachers and students to improve learning", as seen in Table 2.

Table 1. Educational setting and type of institutions where the actions are carried out

\begin{tabular}{lcc}
\hline & N & $\%$ \\
\hline Educational Stages and Modalities & 15 & 51.7 \\
Kindergarten & 18 & 61 \\
Elementary and Middle School & 5 & 17.2 \\
High School & 1 & 3.4 \\
Adult Education & 4 & 13.7 \\
Special Education & 17 & 58.6 \\
\hline Types of Institutions & 11 & 37.9 \\
Public schools & 1 & 3.4 \\
Private schools & & \\
Department of Education &
\end{tabular}


Table 2. Reports on the objectives of the educational speech-language-hearing pathology and the practices developed

\begin{tabular}{lcc}
\hline & N & $\%$ \\
\hline Objectives of the work of the educational speech-language-hearing pathologist & & 38 \\
To help in the teaching-learning process & 11 & 31 \\
To identify weaknesses in the students and refer them to health care is the objective of the educational \\
speech-language-hearing pathologist & 9 & 31 \\
To work along with school administration & 9 & \\
\hline Objectives of the practical activities carried out in the school setting & 17 & 58.6 \\
To carry out activities with the teachers and students to improve learning & 5 & 17.2 \\
To develop activities in the classroom with the students to identify possible changes in oral and written & 7 & 24.2 \\
language & & \\
To hold meetings with teachers and principals to understand the school dynamics
\end{tabular}

\section{Students' report on the SLH training to work in education}

Figure 2 shows what the participants report in the research regarding the SLH pathologist's training for their professional work, which was considered average by most of them (58.9\%).

When asked about the reasons, the students pointed out that the course load regarding educational
SLH pathology "is low" and "little is said/discussed about the field during their training". The most mentioned necessary improvements in educational $\mathrm{SLH}$ pathology training include the "course separately given in theoretical and practical moments" (45.2\%), "having more practical activities" (13.7\%), and "having more courses relating SLH to education" (27.4\%). It should be emphasized that (13.7\%) reported "no need for improvements in the training".

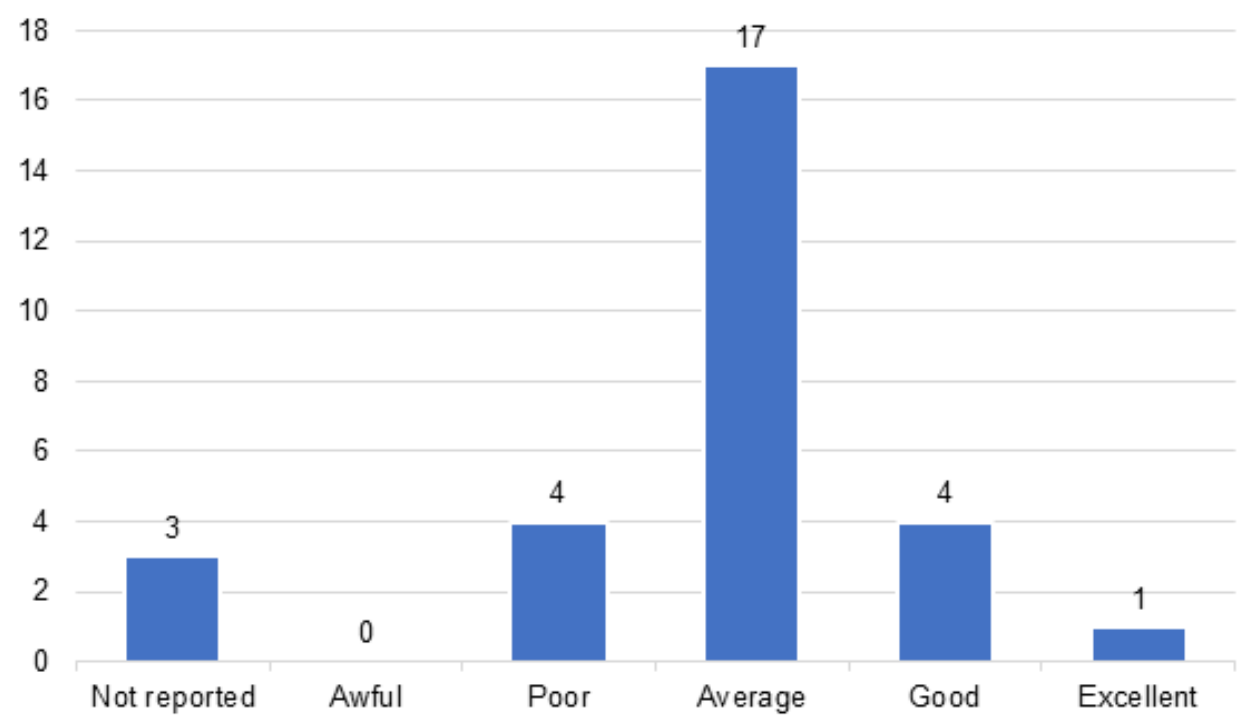

Figure 2. Evaluation of the training in Educational Speech-Language-Hearing Pathology

\section{DISCUSSION}

Based on the collected data, it was verified that the students at HEI-A had contact with four courses; two of them were elective and were not taken by all the interviewees. Anyhow, the summed course load of the education-related courses offered at both HEI is still low. According to the information in the curricula of the SLH programs of the HEI at the time of collection, the total course load of the SLH program at HEI-A was of 3,600 hours, and at HEI-B, 3,360 hours. Hence, the summed course load of the education-related courses corresponds to $(5.83 \%)$ and $(1.78 \%)$ at both $\mathrm{HEI}$, respectively. 
Along the same line of the data found in this research, a recent study ${ }^{6}$ showed that less than half of the Brazilian undergraduate SLH programs offered specific courses on Educational SLH Pathology. Also, most of those that do offer them, the courses are only theoretical, with a course load of 40 hours or a little more than that. The research concludes that both the percentage of curricular education-related content in the SLH programs and the mean course load aimed at courses on Educational SLH Pathology are low and indicate the need for the SLH training to be quantitatively and qualitatively strengthened regarding the education-related content.

It should also be clarified that, following the recommendations of the National Health Council - Conselho Nacional de Saúde (CNS), the new approach of the National Curricular Guidelines for the Undergraduate Bachelor SLH Program ${ }^{12}$ currently being discussed, foresees a minimum course load of 4,000 (four thousand) hours for the in-person SLH programs, with training coordinated with real-life experiences. Thus, considering that the curricula of the program analyzed here will probably need to undergo course load adjustments to have them increased, it is suggested that the contents and experiences aimed at educational SLH pathology be given priority.

Besides the quantitative factor, it is necessary to analyze the qualitative ones involving the courses. The courses directly related to Educational SLH Pathology at both HEI have a theoretical-practical character. The analysis of these courses' syllabi reveals the use of the term "Health promotion in the school environment" at both $\mathrm{HEI}$, as well as a topic aimed at "inclusion at school".

Nevertheless, such syllabi lack, for instance, content related to legislation, cooperation between health and education, and the educational situation in the municipality where the $\mathrm{HEl}$ are located. It is understood that the initial SLH training to work in educational settings must have a critical-reflexive approach and encompass the public health and education policies, besides the documents that guide the educational practices in Brazil - e.g., the Federal Constitution, Law on Guidelines and Bases (LDB, in Portuguese), National Curricular Parameters (PCNs), National Common Curricular Basis (BNCC), National Policy on Special Education in the Perspective of Inclusive Education, National Education Plan (PNE, 2014-2024), State and Municipal Plans, which must be outlined based on the PNE, and at the local level, the Pedagogical Policy Plan of the school where they will work and the training activities will be carried out ${ }^{3,6}$.

It must also be considered that, according to the 2002 National Curricular Guidelines for the SLH Sciences ${ }^{14}$, the SLH pathologist's training must approach, besides health promotion, the social contexts and individual and collective actions integrated with other professionals ${ }^{7,15-17}$. In this regard, it is also considered that the training must provide to the student experiences that go beyond the borders of health, with practices in cooperation between sectors. Moreover, it is necessary to consider that putting the undergraduate student in contact with what is experienced in the educational institutions can motivate them to try to understand situations lived in that specific context, relating them to public policies, programs, and strategies in education. Hence, the practical experience while still in training, besides drawing the future professional nearer the reality they will experience, allows them to notice the existence and development of a wide range of practices and possibilities other than those traditionally known ${ }^{18}$.

Another point to highlight is the importance of establishing a relationship between theory and the practice lived in everyday work - in this case, based on the experiences furnished by the educational practice - to make it possible to maintain the epistemological rigor without losing sight of the true needs of the setting where they will work ${ }^{19}$.

Thus, it is observed that the possibilities furnished by the two $\mathrm{HEl}$ - in which only one course directly related to Educational SLH Pathology is offered, with a total course load of 60 hours, where the students both learn theoretical content and are required to plan and carry out practical activities - do not cover the need for necessary content for the SLH pathologist, even in a generalized training, to propose truly significant actions, apart from the clinical practice and aimed at promoting health and learning. Furthermore, it is necessary to call attention to the fact that the social contexts proposed by the National Curricular Guidelines are approached only in the course on "Special education in the inclusive perspective", offered at HEl-A. However, the syllabus itself relates this concept to disability alone, suggesting also a medical-centered model.

It is necessary, then, to reflect to what extent a training - in which few hours are aimed at discussing the work in education and does not study the existing educational policies and programs in the country, state, or municipality where the training actions take place - enables those who graduate to feel prepared 
to promote differentiated and significant actions. This is reflected, for instance, in the number of professionals specialized in Educational SLH Pathology in the region of the System of SLH Councils to which the municipality belongs.

According to the website of the Conselho Federal de Fonoaudiologia ${ }^{20}$ (Federal SLH Council), in this region, which comprises five Brazilian states, there are currently only five professionals with such a title. Moreover, another piece of research ${ }^{21}$ demonstrated that most of the educational SLH pathologists that sought continuing education are specialized in audiology and orofacial motor functions. Hence, a question arises: Is the SLH training providing what is necessary for those who graduate to consider the educational setting as a potential field of work? Also: Is the initial and continuous education considering the need for critical-reflexive training to work with education, or is it only intuitively and repetitively reproducing techniques of a clinical and noncritical model?

To answer such questions, the above data must be related to others regarding the educational settings where the practical activities of the courses are carried out. According to most of the participants, elementary school is where most of these actions take place, followed by kindergarten; these two contexts were mentioned by more than half of the participants. Such data agree with what is pointed out in a previous study ${ }^{22}$, which can be explained, among other aspects, by the fact that it is precisely in these settings that the children's linguistic manifestations are frequently considered as errors and/or deviations.

Another point that calls attention is the few actions developed in special education, mentioned by only four participants (13.7\%), as the work of the educational SLH pathologist is oftentimes related precisely to students with some established diagnosis and/or changes ${ }^{5}$. Nonetheless, these data suggest that such a group has not been given priority in practical training.

The finding leads to the reflection on whether such practice is moving away from a curative model (still defended by many Brazilian SLH pathologists who see the school as another potential place to conduct rehabilitating practices) or the focus continues on finding the needs, identifying possible changes that might influence the learning process, justified by preventing disorders - which calls to pondering on the objectives of such practice.

The reflection may be complemented by the answers obtained with the questionnaire regarding the objectives of the educational SLH pathologist's work. As presented, most of the research's participants pointed out the specific objectives of the practical activities carried out in the course as "to improve learning". Concerning the general objectives of the educational SLH pathologist's work, most of the students understand this professional must "help in the teaching-learning process", both cooperating with the school administration and focusing on the students, to "identify changes and/or refer them to health care when necessary".

Probably, such an issue is directly related to the low course load and restricted content the students had been submitted to. In the format these courses are being offered to them, no discussions seem to be made possible, neither are the experiences broadened. Concerning these data, it is also important to highlight the terms used by these students: "improve learning" may be a reductionist objective, since it only considers one side of the schooling process - that of the learner. Hence, besides not considering the process itself, it also puts aside the important work of the SLH pathologist in partnership with education professionals and at other levels of education.

Nonetheless, when pointing out that the general objectives of the educational SLH pathologist are to "help" in the teaching-learning process, and even considering the SLH work with teachers and administrators, it still refers to a verticalized practice, in which the SLH pathologist is still considered an agent foreign to education, who approaches it as one who possesses the knowledge and solutions to possible problems found in the educational process, revealing a verticalized relationship $p^{4,5,23}$.

In contrast, it is considered here that such a relationship must be based on the concept of cooperation between sectors, understood as a possibility to promote and coordinate practices that consider the importance of the socio-historical, economic, political, and ideological determinants in the school setting ${ }^{3}$. Hence, the actions proposed must result in the empowerment of the health and education professionals, school public, family, and community, with no knowledge overshadowing the others. Thus, there must be a more humanized and horizontal relationship ${ }^{23}$.

It is necessary to further highlight the answers pointing out as objectives the actions aimed only at "identifying changes and referring the students when necessary". Based on these data, it is considered that the objectives listed by the students in this research are 
still related to those of the practice traditionally used by SLH pathologists ever since the profession appeared, characterized by essentially clinical actions ${ }^{7,22}$.

Thus, in educational settings, it is necessary to overcome SLH practices that seek to be grounded on the noncritical repetition of reductionist concepts and actions, dichotomizing the normal/pathological and health/disease concepts, presenting a health assistance model, explaining school failure from exclusively individual causes, and deviating the focus from pedagogical issues to the clinical context, legitimizing mistaken labels and stereotypes ${ }^{3}$. Moreover, if education is considered by the SLH pathologists as a field of work, there must be a commitment to training professionals capable of thoroughly understanding this field, to detriment of fragmented and technicist views ${ }^{3,23}$.

The data and discussions presented up to now can explain why the training of the SLH pathologist to work with education was considered average by most of the interviewed students. They referred to the need for both increasing the course load related to education and having more practical activities in this field as important aspects to qualify this training.

In this sense, the educational SLH pathologist must first have the goal of improving the quality of education with actions established in partnership with those who work at the educational institutions. However, for this to happen, the SLH pathologist must have, from their initial training, access to experiences and contents that make it possible for them to propose and develop research and practices broadly coordinated with the principles of education.

Therefore, this professional must be committed to improving the quality of education and preparing for citizenship. Hence, they can contribute to substantial changes that give the Brazilian people access to and acquisition of written language, as well as the improvement of the quality of teaching ${ }^{23}$.

Furthermore, they must promote interventions and practices to transform education as part of social transformation. These changes cannot be imposed; they must be developed day by day in the educational setting in partnership with teachers, administrators, and coordinators, so their practices are mingled with reflection, experimentation, questionings, and, above all, development of paths that both come and go, raising awareness, the means for them to take on the responsive authorship of their practices, as well as a political, critical, and ethical standing amidst the educational processes, as part of a broader social transformation process ${ }^{23}$.

In this regard, the work of the educational SLH pathologist must aim at community practices and actions - a work permeated by and with implications to social and especially political issues. Hence, the circumstances involving teaching-learning can be reviewed to promote changes in the schooling process of children and adolescents and devise strategies to keep public teaching from becoming superficial and empty ${ }^{10}$.

It is also important for the SLH pathologist to promote and coordinate practices that help to reach a broader understanding of the socio-historical, economic, political, and ideological determinants that permeates the school setting. Thus, the paradigms of inclusion and health promotion will be coordinated as a central pillar in the process of transforming/overcoming restrictive concepts and actions - which led to mistakes resulting in further educational and social exclusion) and the interaction/partnership between SLH and education professionals and their coordination in service networks ${ }^{3}$.

Hence, a coherent path to foment and support approaches on both initial and continuing education is to strengthen the partnership between the various organs that represent the SLH pathologist, the university, and these professionals, to ensure that these training approaches are mutually coordinated, as well as with the educational and social reality ${ }^{4}$.

Therefore, the uniqueness of each educational setting must be considered, as well as the social, cultural, and historical aspects involved in the teachinglearning process throughout the SLH academic training. They must also get acquainted with the public education and health policies, which are of great importance in their training's improvement process toward a more critical-reflexive, effective, and significant work in this context.

Thus, it is emphasized that reflecting on the SLH practices in educational settings needs to be continuous, as well as the investments in this process of collective construction of the educational SLH pathologist's working profile meant to be coherent with the perspective of inclusive and quality education - and therefore, in the discussion on the principles, guidelines, and goals constituting this profile. 


\section{CONCLUSION}

The SLH undergraduate students who participated in this research reported that their training to work in educational settings needs to be consciously and responsibly broadened regarding its course load, the content coordinated with public education and health policies, the cooperation between these two fields and in consonance with the actual and effective educational demands. The students also referred to the need to broaden the practical experiences aimed at the interface between SLH and Education.

Understanding that the work established and proposed by the SLH professionals is mainly based on the knowledge coming from their academic training, the related practices must be significant and enable the SLH pathologist to draw nearer the different educational situations experienced throughout the country.

\section{REFERENCES}

1. Silva APG, Barbosa CL, Bonini-Trenche MC. Speech therapists practice in Coexistence and Cooperative Center (CECCO): trajectories and challenges of professional qualification. Distúrb. Comum. 2020;32(1):26-40.

2. Goes TRV, Rocha MCG, Lima BPS, Porto VFA. University extension: profile of the speech-language pathology students of a public university. Distúrb. Comum. 2018;30(3):429-39.

3. Giroto CRM, Felisberto LTS, Ghedini SG. Inclusão e medicalização da aprendizagem. J Res Spec Educ Needs. 2016;16(S1):625-9.

4. Lima ILB, Delgado IC, Lucena BTL, Figueiredo LC. Contributions of the institutional diagnosis for speech-language pathology and audiology practice in schools. Distúrb. Comun. 2015;27(2):213-24.

5. Figueiredo L, Lima ILB, Silva HSE. Representations of educational professionals for speech-language and hearing sciences practice in schools. Disturb. Comunic. 2018;30(1):186-93.

6. Moura CSC, Moura GS, Lima ILB, Santos AE, Sousa MS, Oliveira LF. Educational SpeechLanguage Pathology in the curricula of SpeechLanguage Pathology Programs in Brazil. Rev. CEFAC. 2020;22(3):e1320.
7. Sanabe Junior G, Guarinello AC, Santana APO, Berberian AP, Massi GA, Bortolozzi KB. Speech-Language Pathology undergraduates' views about Educational Speech-Language Pathology from their theoretical and practical experiences. Rev. CEFAC. 2016;18(1):198-208.

8. Conselho Federal de Fonoaudiologia. Resolução n. 387: Sobre as atribuições e competências do profissional especialista em Fonoaudiologia Educacional reconhecido pelo Conselho Federal de Fonoaudiologia [base de dados da internet] Brasília: CFFa; 2010.

9. Conselho Federal de Fonoaudiologia. Resolução № 309, 01 de abril de 2005. Dispõe sobre a atuação do Fonoaudiólogo na educação infantil, ensino fundamental, médio, especial e superior, e dá outras providências. Brasília; 2005.

10. Oliveira DPC. Concepções e práticas na fonoaudiologia educacional: reflexões sobre a atuação do fonoaudiólogo na rede básica de ensino [Dissertação]. Salvador (BA): Universidade Federal da Bahia, Faculdade de Educação; 2018.

11. Trenche MCB, Bizerra MP, Ferreira LP. Interface entre Fonoaudiologia e Educação: análise da produção em periódicos científicos. Distúrb. Comunic. 2011;23(3):357-63.

12. Conselho Nacional de Saúde. Resolução n610, 13 de dezembro de 2018. Recomendações do Conselho Nacional de Saúde (CNS) à proposta das diretrizes curriculares nacionais do curso de graduação bacharelado em Fonoaudiologia; 2018

13. Silveira JLGC, Garcia VL. Mudança curricular em Odontologia: significados a partir dos sujeitos da aprendizagem. Interface. 2015;19(52):145-58.

14. Conselho Nacional de Educação. Resolução CNE/ CES 5/2002. Diário Oficial da União. Brasília, 4 de março de 2002. Seção 1, p.12.

15. Baptista GCS. A importância da reflexão sobre a prática de ensino para a formação docente inicial em ciências biológicas. Ens. Pesqui. Educ. Ciênc. 2003;5(2):86-96.

16. Leite ACS, Silva PAB, Vaz ACR. A importância das aulas práticas para alunos jovens e adultos: uma abordagem investigativa sobre a percepção dos alunos do PROEF II. Ens. Pesqui. Educ. Ciênc. 2005;7(3):166-81.

17. Limeira RRT, Silva SM, Figueiredo SC, Castro RD, Figueiredo-Oliveira L, Oliveira MIF. Estágio em Saúde Coletiva: formação em Fonoaudiologia. Rev Ciênc Plural. 2018;3(3):93-110. 
18. Trenche MCB, Oliveira RB, Vicentim MC, Pupo AC. Professional training in Speech-Language Pathology and Audiology: the experience report of a student in Education Program at Work - PetSaúde Mental Health. Distúrb. Comum. 2015;27(3):618-30.

19. Joia JH, Matsumoto AE, Trenche MCB, Bezerra F, Affonso $\mathrm{K}$, Oliveira $\mathrm{S}$. The $\mathrm{SACl}$ project: training for work in Health Education. Distúrb. Comum. 2017;29(4):782-92.

20. Consulta especialistas por especialidade/região [homepage da internet] Brasília: Conselho Federal de Fonoaudiologia; 2020 [acesso em: 29.03.2020]. Disponível em: https://www.fonoaudiologia.org. $\mathrm{br} / \mathrm{cffa} /$ index.php/consulta-especialistas-porespecialidaderegiao/ acesso em 14.05.2020.

21. Celeste LC, Zanoni G, Queiroga B, Alves LM. Hearing and Speech Sciences in educational environment mapping in Brazil: education, work and professional experience. CoDAS. 2017;29(1):e20160029.

22. Oliveira LF, Lima ILB, Lucena BTL, Nascimento BL, Filgueira LL, Mendes LEC et al. Educational institutions as a field for speech-language-hearing research: an analysis of publications in Brazilian journals. Rev. CEFAC. 2020;22(3):e16719.

23. Bortolozzi KBB. Fonoaudiologia e Educação: a constituição de uma parceria responsiva ativa [Tese]. Curitiba (PR): Universidade Tuiuti do Paraná, Faculdade de Ciências Biológicas e da Saúde; 2013. 